\title{
Donor Characteristics of Intestinal Graft in Turkey
}

\author{
Türkiyedeki Intestinal Donor Greftlerinin Özellikleri
}

\author{
İsmail Sert $\oplus^{\oplus}$, Cem Tuğmen $\odot$, Maşallah Baran $\odot$, Sait Murat Doğan $\odot$, Emran Kuzey Avcı $\odot$, \\ Eyüp Kebabçı ๑
}

\section{Özgün Araştırma Research Article}

Received/Geliş: 22.03.2019 Accepted/Kabul: 24.06.2019 Published Online: 31.08 .2020

İsmail Sert

Sağıık Bilimleri Üniversitesi Tepecik Eğitim ve Araştırma Hastanesi, Organ Nakli Kliniği, Izmir - Türkiye

$\checkmark$ drismailsertege@yahoo.com ORCID: 0000-0001-5190-9124

C. Tugmen 0000-0002-2668-5197 E.K. Avcı 0000-0002-9221-4959

E. Kebabçı 0000-0001-8900-2325 Sağlık Bilimleri Üniversitesi Tepecik Eğitim ve Araștırma Hastanesi, Organ Nakli Kliniği, izmir, Türkiye

M. Baran 0000-0003-3827-2039 Katip Çelebil Üniversitesi Tıp Fakültesi, Pediatrik Gastroenteroloji Anabilim Dalı, İzmir, Türkiye

S.M. Doğan 0000-0001-8840-4365 Inönü Üniversitesi Tıp Fakültesi, Karaciğer Nakil Enstitüsü, Malatya, Türkiye

This study is presented in $1^{\text {st }}$ International Transplant Network Congress, Antalya, 2018 as a poster presentation.

Cite as: Sert I, Tuğmen C, Baran M, Doğan SM, Kuzey Avcı E, Kebabçı E. Donor characteristics of intestinal graft in Turkey. Tepecik Eğit. ve of intestinal graft in Turkey. Tepecik
Araşt. Hast. Dergisi. 2020;30(2):164-8.

\section{ABSTRACT}

Objective: Intestinal transplantation is a challenging procedure and many factors effect the success of the intestinal transplantation. One of the important point is selection of the suitable donor. The characteristics of suitable donor for intestinal graft have not well defined yet. The purpose of the present study is to analysis the characteristics of intestinal graft in Turkey and discuss the results with those reported in the the literature.

Method: We retrospectively analyzed the donor characteristics (age, weight, cause of death, blood type, creatinine level, serum $\mathrm{Na}$, etc.) of intestinal graft in Turkey. Also medical records of recipients like; age, weight, waiting time on the list, etc. were analyzed. The results were presented by percentages and numbers.

Results: Forty-two patients with intestinal failure were registered for intestinal transplantation since 2003. Thirtytwo patients underwent intestinal transplantation. Five patients on waiting list died. The present study includes full data of 24 intestinal grafts and intestinal transplant recipients. Only14 (58.3\%) donors met The Organ Procurement and Transplantation Network (OPTN) criteria for intestinal transplantation. Sixteen (\%66) donors were male. Median donor age and weight were 29 years and $75 \mathrm{~kg}$, respectively. Median stay of the donor at Intensive care unit (ICU) was 3 days. Median donor/recipient body weight ratio was 1,41 (min: 0,84,max: 8,00). Ideal weight match was obtained for only 5 (20.8\%) transplantations $(1,1-0,76)$.

Conclusion: Intestinal transplantations are being performed in Turkey. Due to donor shortage, ideal donors are not available for use in Turkey. For pediatric donors, reduced size intestinal grafts might be used, but unfortunately recipient-donor weight match is still the most essential problem for improvement of intestinal transplantation procedures.

Keywords: Intestinal transplantation, intestinal graft, donor characteristics, reduced size graft, donor recipient body/weight ratio

\section{öz}

Amaç: Bağırsak nakli başarısı birçok faktöre bağımlı olan oldukça zor bir prosedürdür. Bunlardan en önemlisi uygun donör seçimidir. Uygun intestinal greftin seçilmesini sağlayacak kriterler henüz tanımlanmamıştır. Bu çalışmada Türkiye'deki bağırsak greftlerinin donör özelliklerini analiz etmeyi ve sonuçları literatürle tartışmayı amaçladık. Yöntem: Türkiyedeki intestinal greftlerin donör özellikleri (yaș, kilo, ölüm nedeni, kan grubu, kreatinin düzeyi, serum $\mathrm{Na}$ vb.) retrospektif olarak incelendi. Ayrıca alııının yaş, kilo, listede bekleme süresi vb. gibi tıbbi kayıtları analiz edildi. Sonuçlar yüzde ve sayılarla sunuldu.

Bulgular: 2003 yılından itibaren bağırsak yetmezliği nedeniyle intestinal transplantasyon yapılmak üzere 42 hasta kayıtı idi. 32 hastaya bağırsak nakli yapıldı. Bekleme listesindeki beş hasta öldü. Bu çalıșa 24 bağırsak nakli alıcısının ve bağırsak greftinin tam verilerini içermektedir. Bağırsak nakli için "The Organ Procurement and Transplantation Network (OPTN)" kriterlerine uyan sadece 14 bağış̧ı $(\% 58,3)$ bulundu. Donör cinsiyetlerinin 16'sı (\%66) erkekti. Ortanca donör yaşı, kilosu sırasıyla 29 ve 75 kg idi. Vericinin median yoğun bakım ünitesi (YBü) kalış süresi 3 gün, ortanca donör alııı vücut ağırlığı oranı 1.41 idi (min: 0,84, maks: 8,00). Ancak, transplantasyonların sadece 5'i $(\% 20,8)$ ideal kilo uyumu ile yapıldı $(1,1-0,76)$.

Sonuç: Türkiye'de intestinal transplantasyonlar yapılmaya devam edilmektedir. Donör azlığı, Türkiye'de ideal olmayan donörlerin kullanılmasına yol açmaktadır. Çocuk hastalar için bağırsak greftlerinin küçültülerek kullanılabilir hale getirilmesine rağmen, alıcı - donör ağırlık uyumu hala bağırsak naklinin iyi bir şekilde gerçekleştirilmesindeki en önemli sorundur.

Anahtar kelimeler: Intestinal transplantasyon, bağırsak grefti, donör karakteristikleri, kısaltılmış greft, donör-alıcı vücut ağırlığı oranı
(C) Telif hakkı T.C. Să̆lık Bakanlı̆ı İzmir Tepecik Eğit. ve Arasts. Hastanesi. Logos Tip Yayınclık tarafindan yayınlanmaktadır. Bu dergide yayınlanan bütün makaleler Creative Commons Atf-GayriTicari 4.0 Uluslararası Lisansı ile lisanslanmıştır. (c) Copyright Association of Publication of the T.C. Ministry of Health Izmir Tepecik Education and Research Hospital. This journal published by Logos Medical Publishing. Licenced by Creative Commons Attribution-NonCommercial 4.0 International (CC BY) 


\section{INTRODUCTION}

According to 2016 Annual data report of Scientific Registry of Transplant Recipients/Organ Procurement and Transplantation Network (SRTR/OPTN) 2016, the number of Intestinal transplantations is on a stable level during the last two decades (1). Improvements in immunosuppressive treatment and immuno-monitoring and surgical technique have great impact on the decline of graft failure in the field of intestinal transplantation. Turkey had a great advancement in many solid organ transplantations like kidney, heart and liver transplantations. Unfortunately, many of these transplantations are performed using living donors. Although, the number of deceased donors has increased over the time in Turkey (2.7 pm in 2002-7.5 pm in 2013), its is still needed to be improved ${ }^{(2)}$.

Limited number of intestinal transplantations are performed in Turkey. The first intestinal transplantation was performed in 2003 and up to now only 32 intestinal transplantations have been realized in Turkey (2). Intestinal transplantation is a challenging procedure and many factors effect the success of the intestinal transplantation. Main reasons of intestinal graft failure may be summarized as: susceptibility of intestinal graft to ischemia-reperfusion injury and immunologic load of small bowel. One of the important factors for the success of intestinal transplantation is selection of suitable donors.

The characteristics of suitable donor for intestinal graft are not well defined yet. The purpose of the present study is to analysis the donor characteristics of intestinal grafts and discuss the results in line with the current literature. We decided to expand the donor pool without endangering the transplant success may help to improve the success of intestinal transplantations. The present study focuses on donor criteria of intestinal grafts from the perspective of a country with donor shortage.

\section{MATERIAL and METHODS}

The data were collected from two intestinal transplant centers which are active in Turkey and reflect all intestinal transplant activities in Turkey. We retrospectively analyzed information retrieved from medical records of 24 donor, and recipient characteristics of intestinal grafts in Turkey. The data regarding the intestinal donor waiting list were also evaluated. Donor characteristics analyzed in this study were age, weight, blood group, cause of death, creatinine level, serum $\mathrm{Na}$, liver enzymes as aspartate transaminase (AST) and alanine transaminase (ALT) levels, Intensive care unit (ICU) stay, vasopressor usage. and donor characteristics of intestinal grafts were compared with the current literature findings. Also the organ donor statistics from database of the Ministry of Health, Republic of Turkey were used to understand the current donation status in Turkey. The results were presented by percentages and numbers. This study was approved by the Local ethic committee of Tepecik training and Research Hospital, İzmir.

\section{RESULTS}

Forty-two patients with intestinal failure were enrolled for intestinal transplantation since 2003. Intestinal transplantation has been performed for 32 patients (28 Tepecik training and Research Hospital, İzmir and 4 Inönü University, Liver Transplant Institute, Malatya) and 5 patients on waiting list for intestinal graft died. 2 patients have excluded from the waiting list because of the worse health condition for transplantation and 3 patients have still been on waiting list for intestinal transplantation. Medical records of 8 donors have not been reached. The present study includes all data related to 24 intestinal transplant recipients and intestinal grafts.

Seven intestinal recipients were in the pediatric age group. Forty-five percent of intestinal recipients 
were male. Median recipient age and weight were 38 years (min 7 months, max 72 years) and 46 (min: $6 \mathrm{~kg}$ max: $83 \mathrm{~kg}$ ) kg, respectively. Median waiting time on transplantation list was 27 days (min: 3 days, max: 365 days).

Only 14 (58.3\%) donors met the OPTN criteria for intestinal transplantation. Except one, all pediatric intestinal transplantations were performed by donors who met OPTN criteria. All intestinal grafts were procured from brain- dead donors. All donors had negative virology for Human Immune deficiency virus (HIV), Hepatitis B surface antigen/Core antibody (HbsAg/Cab) and Hepatitis $C$ virus Antibody (HCV Ab). Sixteen (\%66.6) donors were male. Median donor age and weight were 29 years and $75 \mathrm{~kg}$, respectively. Only one donor was in the pediatric age group (3 years old). Median ICU stay of the donor was 3 days (min: 1 day, max: 12 days). Median donor recipient body weight ratio was 1.41 (min: 0.84, max: 8.00). Ideal weight match (1.1-0.76) was obtained for only 20.8 percent of transplantations. Only 7 (29.2\%) intestinal donors had identical blood groups. Median cold ischemia time (CIT) was 385 minutes (minimum: $250 \mathrm{~min}$, maximum: $540 \mathrm{~min}$ ). Six donors were not under vasopressor treatment at recovery and 2 donors were under treatment with two vasopressor drugs at recovery. Median creatinine level was $1.1 \mathrm{mg} / \mathrm{dl}$ (min: 0.4, max: $2.0 \mathrm{mg} / \mathrm{dl}$ ). Median serum $\mathrm{Na}$ level was $145 \mathrm{mmol} / \mathrm{L}$ (min: 131mmol/L, max:
$170 \mathrm{mmol} / \mathrm{L})$. Except one case, all donors had liver enzymes as AST and ALT < $500 \mathrm{UI} / \mathrm{L}$. Donor characteristics of intestinal grafts were summarized in Table 1.

For all pediatric intestinal transplantation recipients except two cases, reduced -size intestinal grafts were used. In these two cases, one graft was removed during the operation and the other one was removed after 48 hours due to the graft thrombosis. Except one pediatric case who received jejunal graft, ileojejunal graft was used for all recipients.

Twenty-nine percent of the intestinal transplant recipients were hyper sensitized prior to transplantation. Graft and patient survival rates at 1 year for 7 pediatric recipients were identical (71\%). For all 17 recipients, graft and patient survival rates were also the same (37.5\%).

\section{DISCUSSION}

Intestinal transplantation is performed in a limited number of transplant centers and many of these centers have low volume. Seventy-six percent of intestinal transplantations were performed in North America ${ }^{(3)}$. According to OPTN/SRTR 2016 annual data report, deceased organ donations were perforrmed using 9971 donors in 2016 and $1.5 \%$ of these donor intestinal grafts were used for Intestinal transplantations ${ }^{(4)}$. The number of brain- dead patients in

Table 1. Donor characteristics of intestinal grafts.

\begin{tabular}{|c|c|c|c|c|}
\hline & Median & Percentage & Numbers & Minimum-maximum \\
\hline Donor Age & 29 yrs & & & 3 yrs-60 yrs \\
\hline Donor sex & & $100 \%$ & $\mathrm{n}: 24$ & \\
\hline Female & & $33.3 \%$ & $\mathrm{n}: 8$ & \\
\hline Male & & $66.6 \%$ & $\mathrm{n}: 16$ & \\
\hline Donor weight & $75 \mathrm{~kg}$ & & & $15 \mathrm{~kg}-90 \mathrm{~kg}$ \\
\hline ICU stay & 3 days & & & 1 day-12 days \\
\hline Donor recipient body weight ratio & 1.41 & & & $0.84-8.00$ \\
\hline Percentage of ideal weight match & & $20.8 \%$ & $\mathrm{n}: 5$ & \\
\hline Creatinine level & $1.1 \mathrm{mg} / \mathrm{dl}$ & & & $0.4-2.0 \mathrm{mg} / \mathrm{dl}$ \\
\hline Serum Na level & $145 \mathrm{mmol} / \mathrm{L}$ & & & $131-170 \mathrm{mmol} / \mathrm{L}$ \\
\hline AST and ALT level>500 & & $4.1 \%$ & $\mathrm{n}: 1$ & \\
\hline Vasopressor usage & & $33.3 \%$ & $\mathrm{n}: 8$ & \\
\hline Cold ischemia time & $385 \mathrm{~min}$ & & & $250-540 \mathrm{~min}$ \\
\hline Blood group identical & & $29.2 \%$ & $\mathrm{n}: 7$ & \\
\hline
\end{tabular}

ICU-Intensive care unit, yrs-years, kg-kilograms, AST- Aspartat transaminase, ALT- Alanin Transaminase 
Turkey were 12670 between Jan 2011 and Jan 2018. During this period, organ donation rate was only 24 percent ${ }^{(2)}$. Unfortunately, most of the organ transplantations like liver and kidney are performed from living donors in Turkey. Only $23.8 \%$ of solid organ transplantations were performed with grafts harvested from deceased donors in 2017. Donor pool is very limited. Current condition in Turkey is disadvantageous for procurement of suitable intestinal grafts. Present study revealed that, only fourteen donors (58.3\%) met The USA Organ Procurement and Transplantation Network (OPTN) criteria for intestinal transplantation. It is one of the obstacles to improve the intestinal transplant activity in Turkey. Nowadays, intestinal transplantation from living donors is not common worldwide and reserved for selective patients. Living donor for intestinal graft maybe an option for especially pediatric age group in near future.

According to a comprehensive review including 3504 publications about intestinal transplantations; any of published studies had not specifically reported the donor characteristics ${ }^{(5)}$. The most mentioned donor criteria was donor age. Other factors were not dealt with constantly ${ }^{(5)}$. Analysis of these studies suggests that the donor age for intestinal graft should be 0-50 years. OPTN donor criteria for acceptation of intestinal graft also suggest the donor age to be under 50 years of age ${ }^{(6)}$. But when histopathological and molecular allograft injury characteristics and their relations with multi-organ donors were analyzed, graft histology did not differ in donors aged under and above 50 years ${ }^{(7)}$. In our study five donors were above 50 years old. We all know that extended criteria for donors are being used for liver and kidney transplantations, and improvement of the intestinal transplant results may lead to accept older donors for intestinal transplantation so as to expand the donor pool. The donor's age may not be a contraindication for intestinal donation alone.

Cold ischemia time (CIT) is an important and modifi- able risk factor for structural graft quality. Graft quality has a strict correlation with the transplant outcomes ${ }^{(7)}$. Present study shows that CIT was kept under 9 hours for all intestinal grafts. According to OPTN donor criteria for acceptation of the intestinal graft, CIT should be shorter than 9 hours ${ }^{(6)}$. But there are also some reports with good results for CITs shorter than 12 hours ${ }^{(5)}$. In a study that evaluated the histopathologic injury features in multi- organ donors, there was no histologic difference among grafts harvested from donors under CITs below and above 9 hours ${ }^{(7)}$. But critical threshold for CIT could not be confirmed ${ }^{(7)}$. Current approach is to keep the CIT under 9 hours but in near future technological developments, like the machine perfusion techniques in intestinal grafts, may prolong acceptable CIT.

Seventy-two percent of 2147 transplant patients were at home prior to primary intestinal transplantation, between 2001 and 2011, according to registry data ${ }^{(3)}$. In South America and Asia, proportionally sicker patients had undergone intestinal transplantation ${ }^{(3)}$. In our series, all patients were hospitalized prior to transplantation. So, patients may be more vulnerable to the resistant infections. This condition also stems from the lack of a well-established home parenteral nutrition service in Turkey.

Primary abdominal closure is a challenging procedure especially for pediatric patients, because of the loss of abdominal domain and intestinal edema after reperfusion. Discrepancy of donor-to-recipient body weight ratio may cause abdominal compartment syndrome and ischemia-necrosis of the graft ${ }^{(8)}$. Ideal donor-to-recipient body weight ratio is defined as 1.1 and $0.76^{(9)}$. Donor-recipient size mismatch leads to rejection of many organs and diminishes the donor pool for intestinal transplantation. One of the solutions to overcome the size mismatch is to use the reduced-size grafts. Our common preference is also to use the reduced-size intestinal grafts for pediatric patients. This technique helps us to use intestinal grafts of the adults for pediatric population, as 
well. Its safety and feasibility have been previously shown in many reports ${ }^{(10)}$. Other options to overcome the abdominal closure problem may be summarized as abdominal reconstruction, use of an expander, absorbable mesh, and abdominal wall transplantation. In many cases the combination of these options is needed.

Intestinal transplantation activity is in progress, in Turkey. Due to donor shortage, ideal donors are not available for use as sources of intestinal graft in Turkey. For pediatric donors, reduced- size intestinal grafts might be used, but unfortunately recipient donor weight mismatch is still the most essential problem for improvement of intestinal transplantation activity.

\section{Study Limitations:}

Present study includes small number of donor data, so statisticall analysis could not be performed. Study results were compared with the current literature results. But this study results are important because it yields a small volume center data of a center in a developing country.

Ethics Committee Approval: The approval of Health Sciences University İzmir Tepecik Health Application Research Center Non-Interventional Ethics Committee was obtained (2018/13-7).

Conflict of Interest: All authors of this manuscript declare that there is no conflict of interest.

Funding: None.

Informed Consent: None (retrospective study).

\section{REFERENCES}

1. Smith JM, Weaver T, Skeans MA, Horslen SP, Harper AM, Snyder JJ. OPTN/SRTR 2016 Annual report: Intestine. Am J Transplant. 2018;18(1):254-90. [CrossRef]

2. https://organ.saglik.gov.tr/OTR/70lstatistik/Organ NakillstatistikKamusal.aspx

3. Grant D, Abu-Elmagd K, Mazariegos G, et al. Intestinal transplant registry report: global activity and trends. Am J Transplant. 2015;15(1):210-9. [CrossRef]

4. Israni AK, Zaun D, Rosandale JD, Schaffhausen C, Snyder JJ, Kasiske BL. OPTN/SRTR 2016 Annual data report: Deceased organ donation. Am J Transplant. 2018;18(1):434-63. [CrossRef]

5. Fischer-Frohlich $\mathrm{CL}$, Konigsrainer $\mathrm{A}$, Scahaffer R, et al. Organ Donation: When should we consider intestinal donation. Transpl Int. 2012;25(12):1229-40. [CrossRef]

6. Mazariegos GV, Steffick DE, Horslen S, et al. Intestinal transplantation in the United States, 1999-2008. Am J Transplant. 2010;10(4):1020-34. [CrossRef]

7. Roskott AM, van Haaften WT, Leuvenink $H G$, et al. Histopatologic and molecular evaluation of the organ procurement and transplantation network selection criteria for intestinal graft donation. J Surg Res. 2014;189(1):143-51. [CrossRef]

8. Alexandrides IJ, Liu P, Marshall DM, Nery JR, Tzakis AG, Thaller SR. Abdominal wall closure after intestinal transplantation. Plast Reconstr Surg. 2000;106:805-12. [CrossRef]

9. Fishbein TM, Bodian CA, Miller CM. National sharing of cadaveric isolated intestinal allografts for human transplantation: a feasibility study. Transplantation. 2000;69:859-63. [CrossRef]

10. Lauro A, Vaidya A. Role of "Reduced size" liver/bowel grafts in the abdominal wall transplantation era. World J Gastrointest Surg. 2017;9(9):186-92. [CrossRef] 